\title{
A MULTI-SOURCE DATA APPROACH FOR THE INVESTIGATION OF LAND SUBSIDENCE IN THE KONYA BASIN, TURKEY
}

\author{
F. Calò ${ }^{1}$, D. Notti ${ }^{2}$, J. P. Galve ${ }^{3}$, S. Abdikan ${ }^{4}$, T. Görüm ${ }^{5}$, O. Orhan ${ }^{6}$, H.B. Makineci ${ }^{7}$, A. Pepe ${ }^{1}$, M. Yakar ${ }^{8}$, F. Balik Şanli $^{9}$ \\ ${ }^{1}$ National Research Council (CNR) of Italy, Institute for the Electromagnetic Sensing of the Environment (IREA), Napoli, Italy - \\ (calo.f, pepe.a)@irea.cnr.it \\ ${ }^{2}$ National Research Council (CNR) of Italy, Research Institute for Geo-Hydrological Protection (IRPI), Torino, Italy - \\ davide.notti@irpi.cnr.it \\ ${ }^{3}$ Department of Geodynamics, University of Granada, Granada, Spain - jpgalve@ugr.es \\ ${ }^{4}$ Department of Geomatics Engineering, Engineering Faculty, Bulent Ecevit University, Zonguldak, Turkey - sabdikan@ beun.edu.tr \\ ${ }^{5}$ Geography Department, Istanbul University, Istanbul, Turkey - tolga.gorum@ @istanbul.edu.tr \\ ${ }^{6}$ Department of Earth and Environment, Florida International University, Miami, USA - oorhan@ fiu.edu \\ ${ }^{7}$ Geomatics Engineering Department, Faculty of Engineering, Selcuk University, Konya, Turkey - bilgehanmakineci@gmail.com \\ ${ }^{8}$ Geomatics Engineering Department, Faculty of Engineering, Mersin University, Mersin, Turkey - myakar@mersin.edu.tr \\ ${ }^{9}$ Department of Geomatic Engineering, Civil Engineering Faculty, Yildiz Technical University, Istanbul, Turkey - \\ fbalik@yildiz.edu.tr
}

Commission VI, WG VI/4

KEY WORDS: Remote Sensing, Differential SAR Interferometry (DInSAR), Small BAseline Subset (SBAS), GRACE, Subsidence, Sinkholes, Groundwater, Turkey

\begin{abstract}
:
Groundwater depletion caused by rapid population growth, global climate change, water resources overexploitation is a major concern in many regions of the world. Consequences are not limited to a non-renewable water loss but extend to environmental degradation and geo-hazards risk increase. In areas where excessive groundwater withdrawal occurs, land subsidence induced by aquifer compaction is observed, resulting in severe socio-economic damage for the affected communities. In this work, we apply a multi-source data approach to investigate the fragile environment of Konya plain, central Turkey. The area, which is under strong anthropogenic pressures and faces with serious water-related problems, is widely affected by land subsidence. In order to analyze the spatial and temporal pattern of the subsidence process we use the Small BAseline Subset DInSAR technique to process two datasets of ENVISAT SAR images spanning the 2002 - 2010 period and to produce ground deformation maps and associated time-series. Results, complemented with meteorological, stratigraphic and piezometric data as well as with land-cover information, allow us to obtain a comprehensive picture of the climatic, hydrogeological and human dynamics of the study area.
\end{abstract}

\section{INTRODUCTION}

Water-related issues became one of the major concerns in many regions around the world, especially in the light of global climate change. In the Mediterranean basin, growing water scarcity poses a serious threat to the sustainable development of the region, and efficient water management practices need to be urgently implemented in order to stop natural resources overexploitation and land degradation.

Among Mediterranean countries, Turkey is classified as a "water-stressed" country with a capita water amount of about $1500 \mathrm{~m}^{3}$ that is estimated to decrease to $1000 \mathrm{~m}^{3}$ by 2050 because of climate change effects and rapid population growth, which will place it among the "water-scarce" countries (Sen, 2013). In particular, the arid and semi-arid Mediterranean, Aegean and central Anatolia regions will be severely affected by water shortage (Şen, 2013). Among these areas, the Konya basin is facing with serious water problems, due to climate change (Ekercin et al. 2013) and lack of planning and efficient water management policies especially in the agriculture sector (Dursun et al. 2012). Indeed, it is estimated that, in 94\% of the agricultural fields, inefficient and highly water consuming irrigation methods are used (Divrak et al. 2010). Moreover, growing water needs are often satisfied by illegal groundwater extraction: among 92,000 wells located in the Konya basin, it is estimated that 66,000 are illegal (August et al. 2008). Such an aquifer overexploitation has relevant environmental impacts in the region. Indeed, groundwater overuse and depletion impact on the hydrological cycle (Gokmen et al. 2013; Gokmen, 2013) but also on biodiversity, ecosystem health, drying up of lakes and wetlands (Durduran 2010; Thakur et al. 2012). Moreover, as a result of the piezometric level decrease, two different processes of land subsidence widely affect the area: the first is the progressive settlement induced by the compression of unconsolidated alluvial soil (Ustun et al. 2014; Ustun et al. 2010) and the second are sudden collapses of subterranean cavities created by rock dissolution and suffosion processes (Dogan \& Yilmaz, 2011; Ozdemir, 2015; Günay et al. 2010; Bayari et al. 2009).

Accordingly, the analysis of the spatial and temporal evolution of land subsidence phenomena may significantly contribute to the risk prevention and urban damage mitigation. However, mapping and monitoring surface deformations at basin scale is not an easy task to be accomplished with traditional groundbased techniques, which usually provide point-wise information and are resource-intensive, thus hampering long-term investigations over large areas. With this respect, the use of space-borne Differential Synthetic Aperture Radar (SAR) Interferometry (DInSAR) techniques (Bürgmann \& Rosen, 2000) in Earth Science studies represents an important step forward, allowing surface deformation analyses at high spatial and temporal coverage. By exploiting the phase difference (i.e., 
interferogram) between two SAR images acquired over the study area at different times, DInSAR is capable to measure ground displacements with centimeter to millimeter accuracy (Massonnet \& Feigl, 1998; Hensley \& Farr, 2013). As a result of the availability of SAR data archive collected by the European Space Agency (ESA) ERS-1/2 and ENVISAT satellites, which gave a big impulse to the research in the SAR data processing, multi-temporal DInSAR approaches have been developed (Ferretti et al. 2001; Berardino et al. 2002; Mora et al. 2003; Werner et al. 2003; Hooper 2008), allowing to generate spatially dense deformation maps and associated timeseries for several applications (Arangio et al. 2013; Calò et al. 2015; Osmanoglu et al. 2011; Notti et al. 2016; Galve et al. 2015).

In this paper, we apply the advanced DInSAR technique referred to as Small BAseline Subset (SBAS) (Berardino et al. 2002) to the analysis of land subsidence extensively affecting the Konya area. For the purpose, we use two datasets of SAR images collected by the ENVISAT satellite along ascending and descending orbits during the 2002-2010 period. As aforementioned, over the last decades the basin has been under strong anthropogenic pressures, experiencing groundwater resources overexploitation and environmental degradation.

Aim of this work is to improve the comprehension of the land subsidence in Konya basin and its correlation with conditioning/triggering factors, by adopting a multi-source data approach, based on the integration of remote-sensed (e.g., ENVISAT, LANDSAT, GRACE) and ground-based (e.g., piezometric, meteorological) data and information.

\section{STUDY AREA}

The study area is located within the Konya basin, central Anatolia, which is the biggest endorheic basin in Turkey with a total surface of about $54,000 \mathrm{~km}^{2}$ and elevations ranging from 900 to $3500 \mathrm{~m}$ a.s.l. (Figure 1). The basin is characterized by a typical arid to semi-arid climate with a long-term average yearly precipitation of $380 \mathrm{~mm}$, and an evapotranspiration of 550-600 mm per year (Gokmen et al. 2013). Despite having low precipitation input, there are extensive and intensive agricultural activities in the region, whose main source of water is the groundwater which is extracted through about 92000 groundwater wells distributed around the basin (Gokmen et al. 2012).

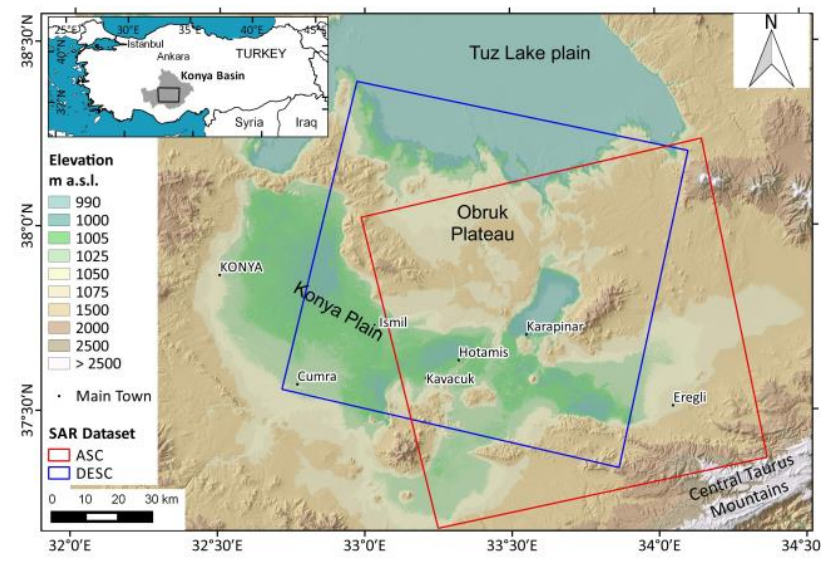

Figure 1. Location and topography of the study area. Frames show the footprints of the ascending (red) and descending (blue) ENVISAT SAR data used in this study.
Geologically, three sectors can be mainly identified: the KonyaKarapinar plain, the Obruk plateau and the volcanic field. The Konya-Karapinar plain is characterized by the presence of lacustrine deposits (unconsolidated clay, silt and sandstone), aeolian and alluvial deposits (Erol 1971; Kuzucuoglu et al. 1998; Dogan \& Yilmaz, 2011). In the Obruk plateau, rocks composed by continental clastics, tuff, limestone and evaporites at the bottom and gypsum-shale alternation at the top outcrop (Bayari et al. 2009); in the western sector of the plateau and along the southern boundary of the Konya plain, formations made up of carbonates and metamorphic rocks are sparsely distributed (MTA 2002). At south-east of Karapinar, a volcanic field, whose activity is related to the extensional phase that originated the Konya basin, is present; cones and other volcanic landforms are visible in the study area.

Along with volcanism, the geomorphological setting of the study area is conditioned by several active processes, as water and wind erosion and rock dissolution. Water erosion and dissolution-induced subsidence are the most widespread phenomena in the study area; in particular, karst depression called "Sinkholes" (locally known as "Obruks") are widely present in the area. Obruks can be classified in two groups (Bayari et al. 2009): old obruks, characterized by large dimensions (up to $640 \mathrm{~m}$ wide), which do not show any evidence of activity; and young obruks, formed during the last decades and characterized by diameters of less than $50 \mathrm{~m}$. The latter are induced by the human-induced lowering of the water table (Dogan \& Yilmaz 2011), and caused several damages in the villages in the Karapinar-Hotamis plain (Figure 2). Indeed, 13 collapse sinkholes (up to $25 \mathrm{~m}$ in diameter) occurred in the period 2006-2009, and it is expected future sudden collapses if the water lowering will continue.

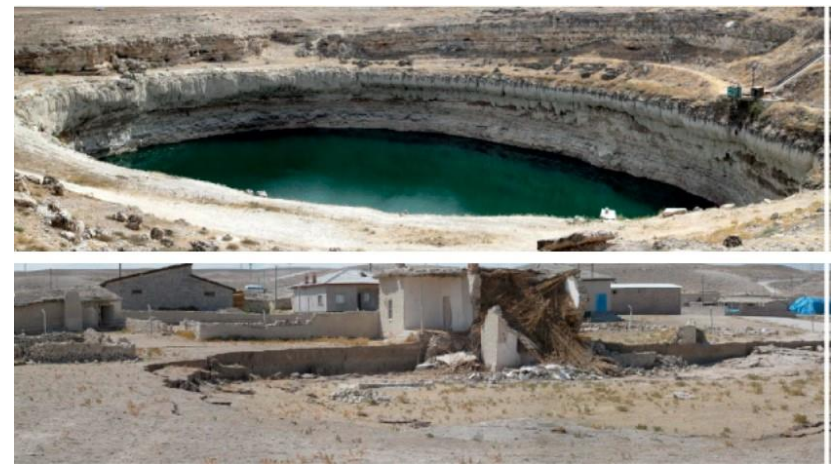

Figure 2. Relict (top) and active (bottom) sinkholes in the area.

\section{DATA AND METHODS}

\subsection{Remote sensed data}

\subsubsection{SAR data}

For our analysis, we used two ENVISAT SAR datasets: 38 images acquired from December 5, 2002 to September 9, 2010 along descending orbits; 27 images collected from December 14, 2002 to June 5, 2010 along ascending orbits (Figure 1). The two geometries (i.e., ascending and descending) were later jointly exploited to compute the horizontal (east-west) and vertical components of the surface displacements.

We applied the SBAS - DInSAR technique (Berardino et al. 2002) based on the selection of SAR data pairs characterized by short temporal (i.e., the time interval between two acquisitions) and spatial (i.e., the distance between two satellite passes) 
baseline in order to reduce noise effects and maximize the number of reliable SAR measure points. In our case, we imposed a constrain of $<400 \mathrm{~m}$ on the perpendicular baseline and of $<1500$ days on the temporal baseline; accordingly, we generated 111 and 73 interferograms from the ENVISAT descending and ascending datasets, respectively. As a next processing step, we computed differential interferograms (i.e., containing only the deformation phase component) by using Digital Elevation Model (DEM) produced by the Shuttle Radar Topography Mission (SRTM) with about $90 \mathrm{~m} \times 90 \mathrm{~m}$ spacing. After phase unwrapping (Pepe \& Lanari 2006), such differential interferograms were properly combined to retrieve the evolution of the surface deformation.

\subsubsection{Optical data and Land Cover maps}

For the analysis of the land changes occurred in the area, we used: CORINE Land Cover (CLC) maps relevant to the years 2000 and 2012; Landsat 5 TM acquired on May 2000; Landsat 8 collected May 2015. Landsat images were acquired as Standard Terrain Correction products (Level 1T - precision and terrain correction) from the USGS Glovis Archive.

\subsubsection{GRACE data}

To evaluate the variation of groundwater storage, we exploited data acquired by the GRACE satellite, in particular Level-2 data collected in the 2002-2010 period. The processed data represent the water storage anomaly (expressed in $\mathrm{cm}$ ) calculated on a cell of $100 \mathrm{~km}$ radius with a $25 \mathrm{~km}$ smooth filter. These data provide measurements of the water storage at regional scale, allowing us to integrate the groundwater information derived from the wells.

\subsection{Ground-based data}

\subsubsection{Groundwater data}

A dataset of piezometric wells, measured by the General Directorate of State Hydraulic Works of Turkey, were used to assess the groundwater level in the Konya plain and the Obruk Plateau. In particular, for the analysis of the correlation between water level changes and surface movements we focused on the piezometric measurements monthly conducted between 2003 and 2010, thus matching the period of the SBAS time-series.

\subsubsection{Stratigraphic data}

The stratigraphy of the area was analysed by using 13 boreholes available in (Dogan \& Yilmaz 2011), allowing us to retrieve information about the thickness of compressible layers (clay and silt) which usually influence the processes of groundwaterrelated subsidence (Notti et al. 2016).

\section{RESULTS AND DISCUSSION}

The SBAS-DInSAR processing allowed us to produce, for each available SAR datasets, two main products: a map of the average deformation velocity and, for each pixel, displacement time-series spanning the period December 2002 - July 2010 time interval. Maps showing magnitude and spatial pattern of surface deformation observed from both satellite orbits (i.e., descending and ascending) are reported in Figure 3. Displacements are measured along the Line of Sight (LOS) of the satellite: negative velocity values (yellow to red color) indicate movements away from satellite whereas positive values (cyan to blue) represent movements toward the satellite.
DInSAR measurements are related to a reference point located in an area assumed to be stable, i.e., not affected by deformation (Figure 3).
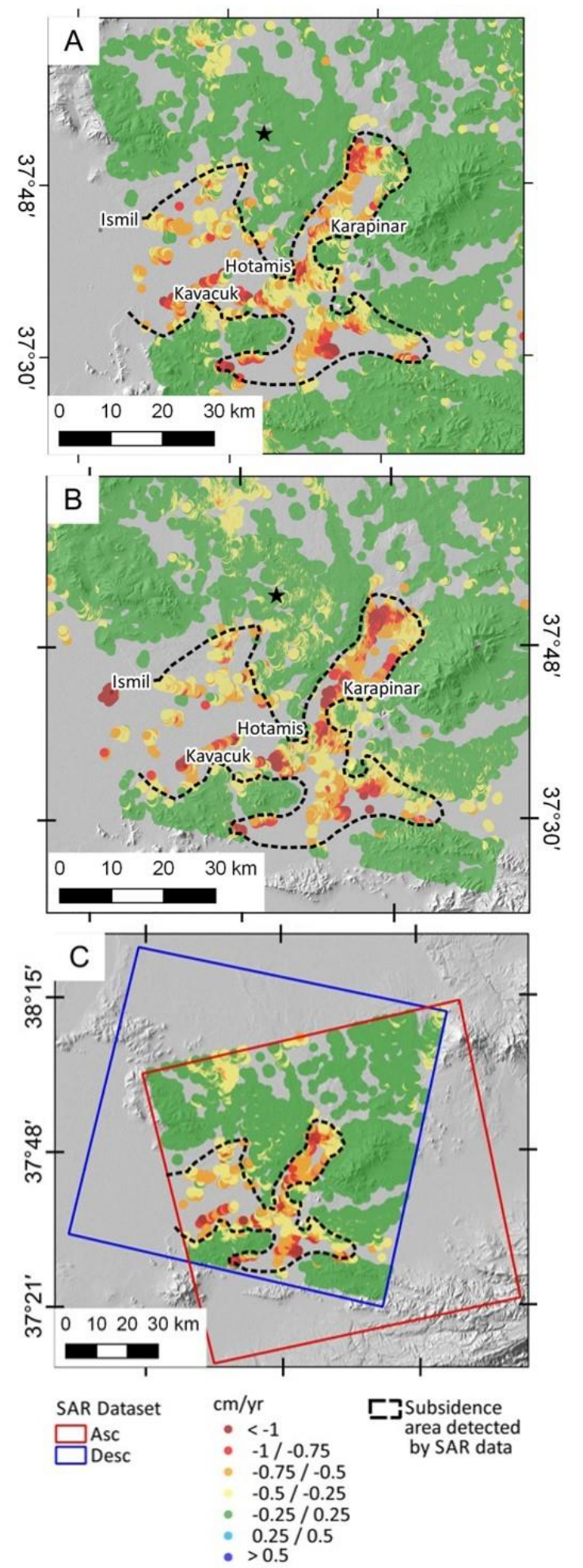

Figure 3. SBAS-DInSAR deformation velocity maps of the study area. (A) and (B) show displacements measured along the satellite LOS during ascending and descending passes, respectively. (C) shows the vertical component of the displacements and the DInSAR derived subsidence area (black dashed line). Black star indicates the reference point. 
After ascending and descending results were attained, we have derived the vertical and (east-west) horizontal components of the surface displacements. The analysis pointed out that the horizontal movement component is negligible while the regional deformation process mainly occurs along the vertical direction; the wide subsidence area extending for $1189 \mathrm{~km}^{2}$ is reported as black dashed line in Figure 3.

As regards the land cover changes, Figure 4 shows the spatial distribution of the CLC classes within the Konya plain in 2000 and 2012 as well as the increase of irrigated areas in this time interval. The analysis pointed out that irrigated lands, pastures and urban areas increased while natural vegetation and water bodies decreased. Such land cover changes usually lead to an increase of water demand which main source, in this area, is constituted by groundwater (Gokmen et al. 2012).
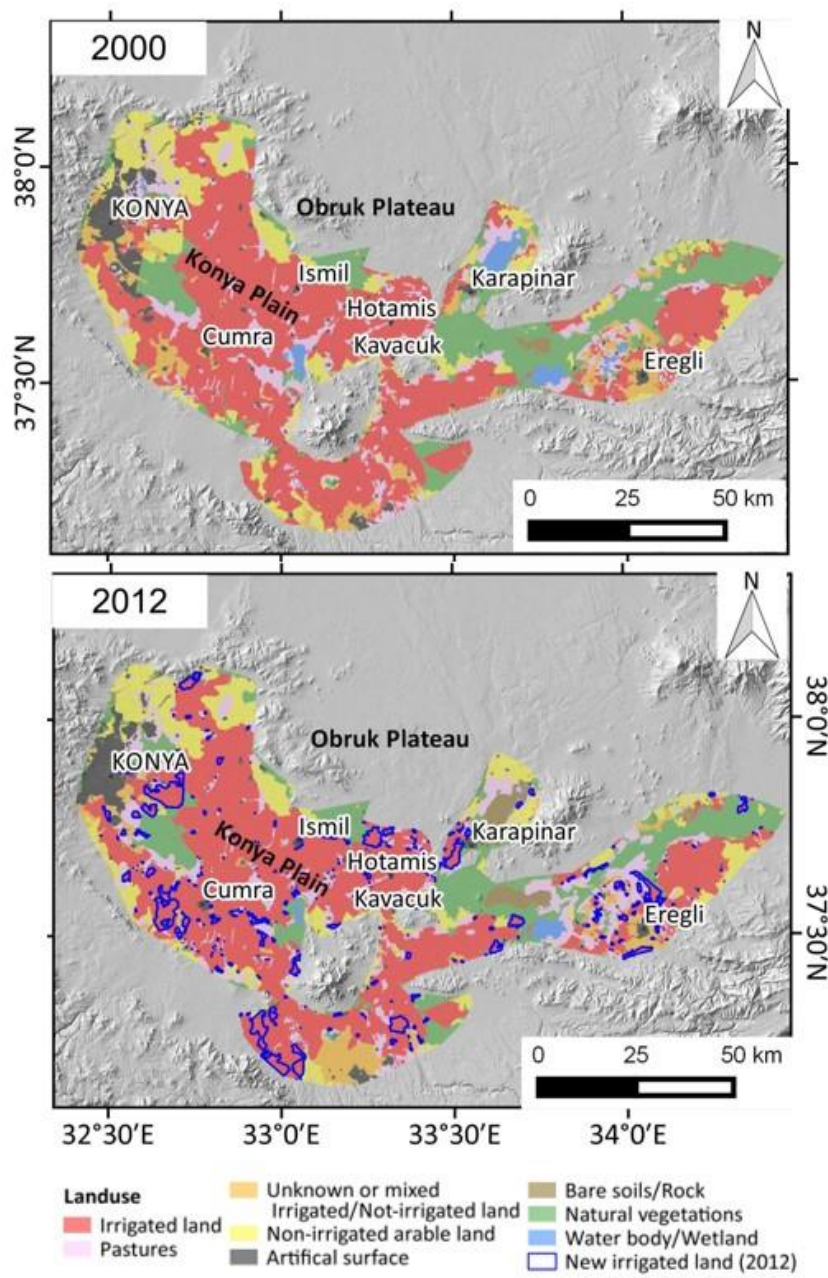

Figure 4. CORINE Land Cover simplified maps of the Konya plain for years 2000 and 2012. Blue polygons in 2012 map

show areas changed from non-irrigated to irrigated.

Land changes associated with groundwater overexploitation were also detected by using a Landsat 5 TM acquired on May 2000 and a Landsat 8 taken on May 2015 (Figure 5). To this aim, we used surface reflectance in the shortwave infrared (SWIR), near infrared (NIR) and blue bands. By inspecting the two images a pattern of crops in 2015 not visible in 2010 is clearly observed, pointing out an increase of land covered by intensive agriculture and irrigated fields over the 15-year period of analysis (Figure 5). Such an observation is not straightforward for the area around Hotamis, probably due to a change in cultivation type that is not visible in the 2015 image.
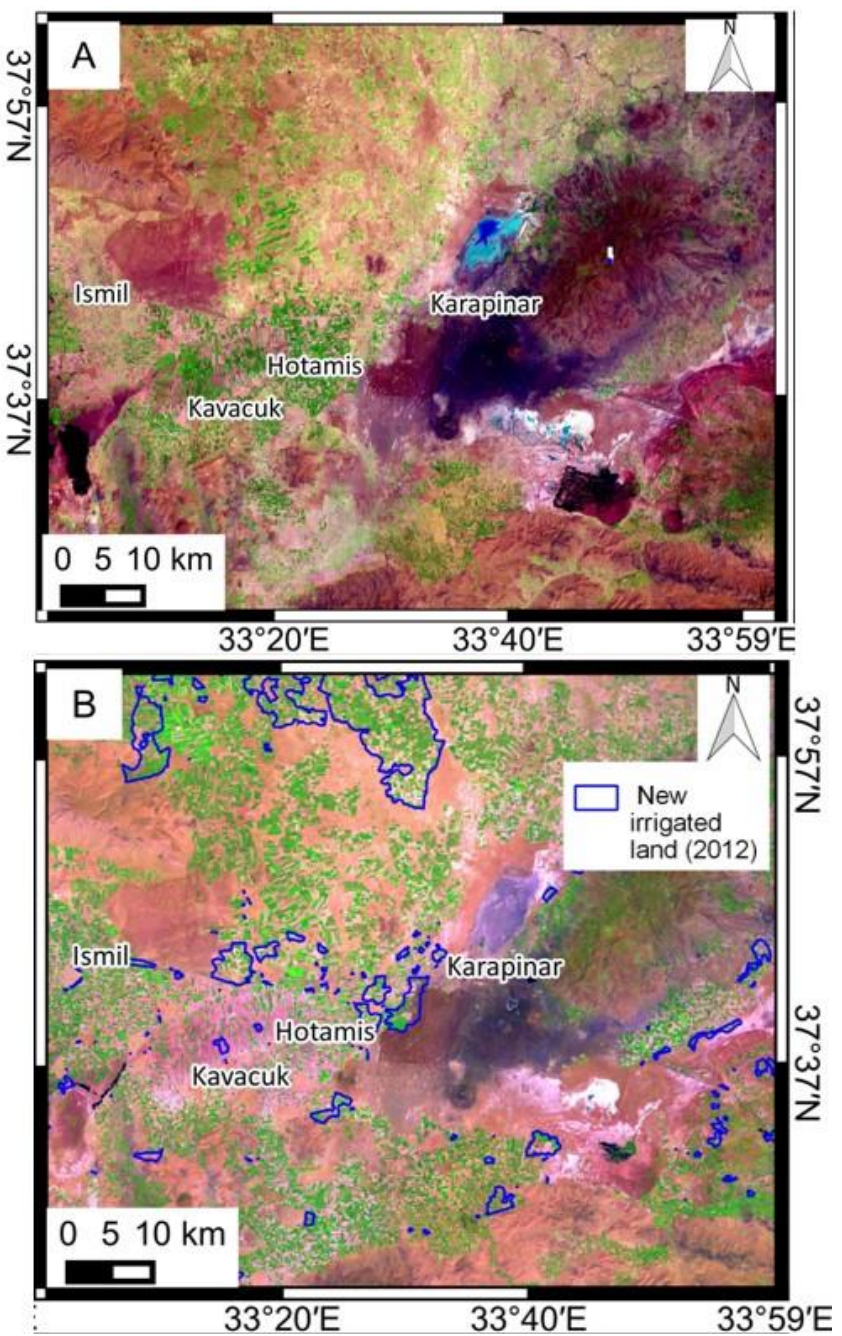

Figure 5. False color images of Landsat $5 \mathrm{TM}$ data $(\mathrm{R}=\mathrm{Band} 5$; $\mathrm{G}=\mathrm{Band} 4$; $\mathrm{B}=\mathrm{Band} 1$ ) acquired on May 2000 (A) and Landsat 8 data $(\mathrm{R}=\mathrm{B}$ and $6 ; \mathrm{G}=\mathrm{B}$ and $5 ; \mathrm{B}=\mathrm{Band} 2)$ captured on May

2015 (B). Blue polygons show areas changed from nonirrigated to irrigated in the 2000-2012 period (see Figure 4).

Landsat images were also classified by applying a supervised classification based on the maximum likelihood method Results are in agreement with CORINE maps, showing that irrigated lands increased from $7 \%$ to $14 \%$ and not-irrigated lands decreased from $26 \%$ to $11 \%$.

We also calculated a modified Normalized Difference Vegetation Index (mNDVI) for the two Landsat images, generally showing an increase of vegetation activity in the cultivated areas (Figure 6). In particular, new irrigated lands (see blue polygons in Figures 4-6) show the highest mNDVI increase, highlighting that most probably the vegetation activity increase is more related to irrigation than to climate.

Finally, we jointly analyzed the SBAS-DInSAR results with the information derived from the other independent data (see Section 3), in order to understand the role of different factors (i.e., type/thickness of lithology, groundwater depletion) in predisposing and/or triggering land subsidence. The correlation analysis pointed out the relationship between the spatial 
distribution of DInSAR derived surface deformations and the thickness of compressible layers (i.e., alluvial deposits are mainly made up of clay and silt) widely present in the plain, showing that high displacement rates affect the areas where the soft sedimentary units are characterized by higher thickness. The relationship between land subsidence and groundwater level variations has been investigated by analyzing piezometric wells and GRACE data as well. In the plain area where soft soils are present, a correlation between piezometric level changes and surface deformation is clearly observed. This is particular evident for some wells, as the one recording a groundwater level decreases of about $12 \mathrm{~m}$ during the 2003 2010 period. For such a well, the near SAR points located in the compressible layer of alluvial sediments show, in this same interval, a cumulated displacement of about $3 \mathrm{~cm}$.

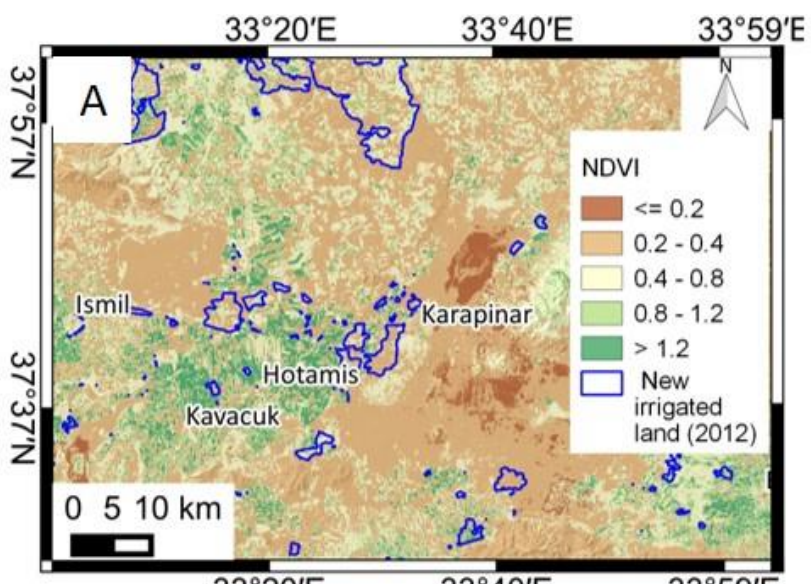

$33^{\circ} 20^{\prime} \mathrm{E}$ $33^{\circ} 40^{\prime} \mathrm{E}$ $33^{\circ} 59^{\prime} \mathrm{E}$

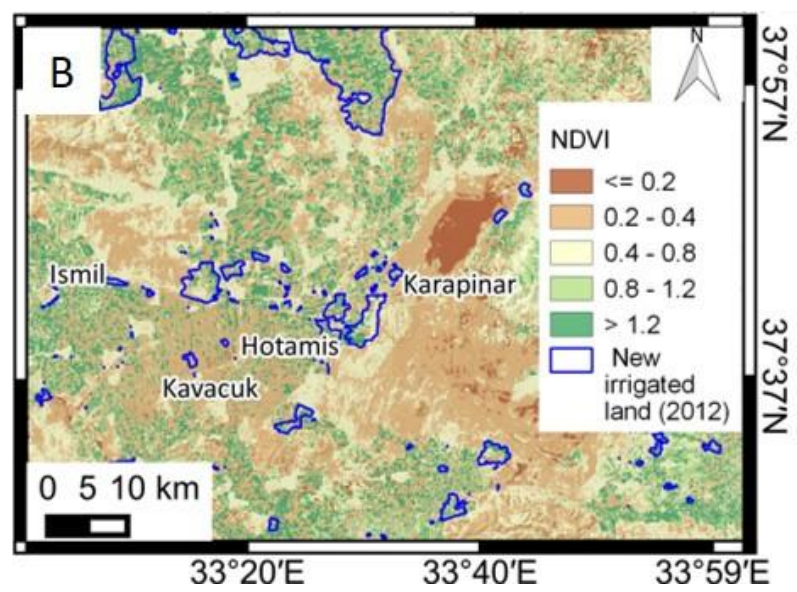

Figure 6. mNDVI index associated to Landsat images reported

in Figure 5. Blue polygons show areas changed from nonirrigated to irrigated in the $2000-2012$ period (see Figure 4).

\section{CONCLUSIONS AND FUTURE PERSPECTIVES}

The study area is located in the Konya basin, which is one of the most important agricultural regions of Turkey, thus playing a strategic role for the economy of the country. Over the last decades, the area became highly vulnerable to climatic and anthropogenic effects. Main pressure is represented by unsustainable agricultural practices, based on uncontrolled irrigation and illegal wells. As a result, groundwater resources and water-dependent ecosystems are under threat. The region experiences environmental degradation, biodiversity loss, draining of lakes and wetlands, droughts. Moreover, groundwater depletion triggered extensive land subsidence in the area, generating great concerns for the Local Authorities because of the high associated risk.

In such a complex environmental context, this work attempts to undertake a comprehensive study to explore the relationship between subsidence hazard and human, climate and geological factors which act as predisposing and/or triggering drivers of ground deformations. To this aim, we used a multi-source data approach which combines remote sensed and in situ data and information. Application of the space-borne SBAS-DInSAR technique allowed us to analyze surface deformations affecting the area and to detect a wide subsidence phenomenon occurring in the plain with rates up to $15 \mathrm{~mm} /$ year. DInSAR observations, in conjunction with available stratigraphic data, reveal that land subsidence mostly takes place where the thickness of the compressible layers of alluvial sediments is higher.

Integration of satellite data and groundwater data allowed us to investigate the relationship between piezometric level decrease and surface deformations, highlighting a correlation between water drawdown and subsidence in the portions of plain where soft soils are present.

This finding, along with the results of land cover changes analysis showing an increase of cultivated and irrigated fields during the observation period, points out the superimposed effect of climate and anthropogenic factors on the depletion of groundwater resources and, accordingly, on the triggering of land subsidence in the plain.

Furthemore, subsidence is also present in the area in the form of sinkholes; these karst collapses are linked with the groundwater lowering and cause heavy damage to buildings and infrastructures. Therefore, more efforts aimed at improving the sinkhole hazard assessment are needed. In this regard, we will extend our analysis to better understand sinkhole precursors and assess the potential for future sinkhole development by exploiting high resolution TerraSAR-X data integrated with Electrical Resistivity methods.

\section{ACKNOWLEDGEMENTS}

The work was financed by the project Space Advanced Project Excellence in Research and Enterprise (SAPERE) within the Italian Program "Sviluppo e Potenziamento dei Cluster tecnologici Nazionali". The activities were carried out through the Infrastructure of High Technology for Environmental and Climate Monitoring-PONa3_00363 project of Structural Improvement financed under the National Operational Programme for "Research and Competitiveness 2007-2013," supported with the European Regional Development Fund and National Resources. ENVISAT ASAR data were provided by European Space Agency (ESA) in the framework of the CAT-1 ESA No. 10050 project.

\section{REFERENCES}

Arangio, S., Calò, F., Di Mauro, M., Bonano, M., Marsella, M., Manunta M., 2013. An application of the SBAS-DInSAR technique for the assessment of structural damage in the city of Rome. Struct. Infrastruct. Eng.: Maint. Manag. Life-Cycle Des. Perform., doi: 10.1080/15732479.2013.833949.

August, D., Geiger, M., 2008. Drought in the Mediterranean. Recent developments. In WWF for a Living Planet. WWF Germany: Frankfurt; pp. 43.

Bayari, C.S., Pekkan, E., Ozyurt, N.N., 2009. Obruks, as giant collapse dolines caused by hypogenic karstification in central 
Anatolia, Turkey: analysis of likely formation processes. Hydrogeology Journal, 17, pp. 327-345.

Berardino, P., Fornaro, G., Lanari, R., Sansosti, E. 2002. A new algorithm for surface deformation monitoring based on small baseline differential SAR interferograms. IEEE Trans. Geosci. Remote Sens., 40, pp. 2375-2383.

Bürgmann, R., Rosen, P.A., Fielding, E.J., 2000. Synthetic aperture radar interferometry to measure Earth's surface topography and its deformation. Ann. Rev. Earth Planet. Sci., 28, pp. 169-209.

Calò, F., Abdikan, S., Görüm, T., Pepe, A., Kiliç, H., Şanli, F. B., 2015. The Space-Borne SBAS-DInSAR Technique as a Supporting Tool for Sustainable Urban Policies: The Case of Istanbul Megacity, Turkey. Remote Sens., 7, pp. 16519-16536.

Divrak, B.B., Ayas, C., Iş G., 2010. Drought trends and impacts on agricultural production and natural resources in the context of climate change. In Economics of drought and drought preparedness in a climate change context, López-Francos A. (comp.), López-Francos A. (collab.), Eds.; CIHEAM / FAO / ICARD A / GD AR / CEIGRAM / MARM: Zaragoza, Spain; pp. $49-55$.

Dogan, U., Y1lmaz, M., 2011. Natural and induced sinkholes of the Obruk Plateau and Karapınar - Hotamıs Plain, Turkey. Journal of Asian Earth Sciences, 40, pp. 496-508.

Durduran, S.S., 2010. Coastline change assessment on water reservoirs located in the Konya Basin Area, Turkey, using multitemporal landsat imagery. Environ. Monit. Assess., 164, pp. 453-461.

Dursun, S., Onder, S., Acar, R. Direk, M., Mucehver, O., 2012. Effect of Environmental and Socioeconomically Change on Agricultural Production in Konya Region. Proceedings of International Conference on Applied Life Sciences, Turkey, September 10-12, pp. 19-36.

Ekercin, S., Sertel, E., Dadaser-Celik, F., Durduran, S., 2013. Investigating the Climate Change Impacts on the Water Resources of the Konya Closed Basin Area (Turkey) Using Satellite Remote Sensing Data. In Causes, Impacts and Solutions to Global Warming, Dincer et al., Eds.; Springer Science+Business Media: New York, USA; pp. 157-168.

Erol, O., 1971. Geomorphological evidence of the recessional phases of the pluvial lakes in the Konya, Tuzgolu and Burdur basins in Anatolia. Ankara University Annals of the Geographical Research Institute, 3-4, pp. 13-52.

Kuzucuoglu, C., Parish, R., Karabiyikoglu, M., 1998. The dune systems of the Konya Plain (Turkey): their relation to environmental changes in Central Anatolia during the Late Pleistocene and Holocene. Geomorphology, 23(2), pp. 257-271.

Ferretti, A., Prati, C., Rocca, F., 2001. Permanent scatterers in SAR interferometry. IEEE Trans. Geosci. Remote Sens., 39, pp. 8-20.

Galve, J.P., Castañeda, C., Gutiérrez, F., Herrera, G., 2015. Assessing sinkhole activity in the Ebro Valley mantled evaporite karst using advanced DInSAR. Geomorphology, 229, pp. 30-44.
Gokmen, M., Vekerdy, Z., Lubczynski, M. W., Timmermans, J., Batelaan, O., Verhoef, W., 2013. Assessing groundwater storage changes using remote sensing-based evapotranspiration and precipitation at a large semiarid basin scale. $J$. of Hydrometeorology, 14(6), pp. 1733-1753.

Gokmen, M., Vekerdy, Z., Verhoef, A., Verhoef, W., Batelaan, O., Van Der Tol, C., 2012. Integration of soil moisture in SEBS for improving evapotranspiration estimation under water stress conditions. Remote Sensing of Environment, 121, pp. 261-274.

Gokmen, M., 2013. Earth Observation for quantifying ecohydrological fluxes and inter-relations: a regional case - the Konya Closed Basin, Turkey. PhD thesis, University of Twente, Enschede, The Netherlands.

Günay, 'G., Çörekçioglu, I., Eroskay, S. O., Övül. G., 2010. Konya Karapınar Obruks (Sinkholes) of Turkey. In Advances in Research in Karst Media. B. Andreo et al. Eds.; Springer, pp. 367-372.

Hensley, S.; Farr, T., 2013. Microwave remote sensing and surface characterization. In Treatise on GeomorphologyRemote Sensing and GIScience in Geomorphology; Shroder, J., Bishop, M.P., Eds.; Academic Press: San Diego, CA, USA, Volume 3, pp. 43-79.

Hooper, A., 2008. A multi-temporal InSAR method incorporating both persistent scatterer and small baseline approaches. Geophys. Res. Lett., 35, L16302.

Massonnet, D., Feigl, K.L., 1998. Radar Interferometry and its application to changes in the Earth's surface. Rev. Geophys., 36, pp. 441-500.

Mora, O., Mallorqui, J.J., Broquetas, A., 2003. Linear and nonlinear terrain deformation maps from a reduced set of interferometric SAR images. IEEE Trans. Geosci. Remote Sens., 41, pp. 2243-2253.

MTA, 2002. 1:500 000 scaled Geology maps of Turkey, Konya, Kayseri and Adana Sheets. MTA (Mineral Research \& Exploration General Directorate), Ankara.

Notti, D., Mateos, R.M., Monserrat, O., Devanthéry, N., Peinado, T., Roldán, F.J., Fernández-Chacón, F., Galve, J.P., Lamas, F., Azañón, J.M., 2016. Lithological control of land subsidence induced by groundwater withdrawal in new urban areas (Granada basin, se spain). Multiband DInSAR monitoring. Hydrological Processes.

Osmanoglu, B., Dixon, T.H., Wdowinski, S., Cabral-Cano, E., Jiang, Y., 2011. Mexico City subsidence observed with Persistent Scatterer InSAR. Int. J. Appl. Earth Obs., pp. 13, 112.

Ozdemir, A., 2015. Investigation of sinkholes spatial distribution using the weights of evidence method and GIS in the vicinity of Karapinar (Konya, Turkey). Geomorphology, 245, pp. $40-50$.

Pepe, A., Lanari, R., 2006. On the extension of the minimum cost flow algorithm for phase unwrapping of multitemporal differential SAR interferograms. IEEE Trans. Geosci. Remote Sens., 44, pp. 2374-2383. 
Şen, O. L., 2013. A. Holistic View Of Climate Change And Its Impacts In Turkey. Istanbul Policy Center, Sabanci University, Istanbul, Turkey, pp. 34.

Thakur, J. K., Srivastava, P. K., Singh, S. K., Vekerdy, Z., 2012. Ecological monitoring of wetlands in semi-arid region of Konya closed Basin, Turkey. Reg. Environ. Change, 12, pp. 133-144.

Ustun, A., Tusat, E., Yalvac, S., Ozkan, I., Eren, Y., Ozdemir, A., Bildirici, O., Ustuntas, T., Kırtıloglu, O. S., Mesutoglu, M., Doganalp, S., Canaslan, F., Abbak, R. A., Avsar, N. B., Simsek, F. F., 2014. Land subsidence in Konya Closed Basin and its spatio-temporal detection by GPS and DInSAR. Environ. Earth Sci., DOI 10.1007/s12665-014-3890-5.

Ustun, A., Tusat, E., Yalvac, S., 2010. Preliminary results of land subsidence monitoring project in Konya Closed Basin between 2006-2009 by means of GNSS observations. Nat. Hazards Earth Syst. Sci., 10, pp. 1151-1157.

Werner, C., Wegmuller, U., Strozzi, T., Wiesmann, A., 2003. Interferometric point target analysis for deformation mapping. In Proceedings of IEEE International Geoscience and Remote Sensing Symposium, Toulose, France, 21-25 July; pp. 43624364 . 